\title{
PENINGKATAN PERTUMBUHAN AWAL STEK BUD CHIPS TANAMAN TEBU PS-881 DENGAN LIMBAH CAIR PETERNAKAN SAPI (Bambang Gunawan ${ }^{1}$, Sri Purwanti $^{2}$, Nurlina $^{3}$, Tatuk Tojibatus ${ }^{4}$ )
}

1,2,3) : Dosen di Bidang Agroteknology Fakultas Pertanian Universitas Merdeka Surabaya 4) : Dosen di Bidang Agroteknology Fakultas Pertanian Universitas Wijaya Kusuma Surabaya

\section{RINGKASAN}

Peningkatan usaha peternakan sapi perah selain memberikan dampak positif yaitu menghasilkan produk utama seperti daging, susu, dan telur juga memberikan dampak negatif karena usaha peternakan pasti menghasilkan limbah. Limbah ternak merupakan sisa buangan dari suatu kegiatan usaha meliputi : limbah padat dan cair seperti feses, urine dan sisa pakan. Dengan menerapkan teknologi tepat guna dengan memanfaatkan limbah cair urine sapi menjadi material penyubur atau pupuk setelah melalui proses pengolahan atau fermentasi guna menjadi pupuk organic yang bermanfaat bagi tanaman. Penelitian ini bertujuan untuk mengetahui pengaruh pemberian konsentrasi POC urine sapi terhadap laju perkecambahan stek bud chips tanaman tebu yang lebih efektif dan effisien. Penelitian dilaksanakan di Kebun Percobaan Fakultas Pertanian Universitas Merdeka Surabaya, dengan ketinggihan tempat \pm 5 meter diatas permukaan laut.

Penelitian ini menggunakan Rancangan Acak Kelompok (RAK), dengan 1 faktor perlakuan yaitu Konsentrasi POC Urine sapi (P) terdiri dari 8 level perlakuan yaitu $0 \mathrm{ml}, 10 \mathrm{ml}, 20 \mathrm{ml}, 30 \mathrm{ml}, 40 \mathrm{ml}, 50 \mathrm{ml}, 60 \mathrm{ml}$, dan $70 \mathrm{ml}$ POC per liter air. Percobaan ini diulang 3 kali dengan tiap-tiap perlakuan terdapat 2 tanaman sampel, sehingga diperoleh 24 perlakuan. Adapun parameter yang diamati antara lain : Kecepatan perkecambahan, diameter batang tunas, jumlah daun, panjang tunas, jumlah akar, panjang akar, dan berat kering per tanaman.

Berdasarkan hasil penelitian, maka dapat disimpulkan sebagai berikut :

1. Terdapat pengaruh signifikan dari konsentrasi POC urine sapi terhadap peningkatan pertumbuhan stek bud chip tanaman tebu pada variabel yang diteliti, meliputi : panjang tunas, jumlah akar, maupun berat kering per tanaman pada masa perkecambahan tanaman tebu.

2. Nilai tertinggi dicapai oleh perlakuan P7 yaitu konsentrasi sebesar $70 \mathrm{ml}$ POC urine sapi per liter air pada semua parameter pengamatan; namun secara statistik nilai terbaik dicapai oleh perlakuan P3 (30 ml POC urine sapi per liter air) karena berbeda tidak nyata dengan perlakuan P7 pada semua variabel yang diteliti, seperti kecepatan perkecambahan, panjang tunas, jumlah daun, panjang akar, jumlah akar dan berat kering per tanaman karena dianggap lebih efektif dan efisien.

Kata Kunci : POC Urine Sapi, Stek Bud Chip tebu. 


\section{PENDAHULUAN}

Perkecambahan adalah suatu tahapan awal dari suatu rangkaian proses yang komplek dari pertumbuhan morfologi, biokimia dan fisiologi tanaman tebu. Perkecambahan merupakan fase kritis bagi tahapan pertumbuhan tebu dan perkecambahan yang baik akan tercapai apabila faktor dalam (genetik) dan luar seperti halnya iklim, tanah, dan teknik budidayanya dalam keadaan optimal. Penyimpanan dari keadaan yang optimal akan menyebabkan kemampuan berkecambah tanaman tebu cepat menurun. Perkecambahan yang baik adalah modal dasar yang baik bagi keberhasilan kebun (Harjadi, 1991) dan (Gunawan, 2018).

Sumberdaya alam berupa air, oksigen, karbondioksida, makanan dan sinar matahari selama periode pertumbuhan tebu sangat dibutuhkan, namun laju kebutuhan setiap fase pertumbuhan tanaman tidak selalu sama. Dengan demikian terdapat ukuran-ukuran kebutuhan yang secara keseluruhan sangat ditentukan oleh kebutuhan biologi pertumbuhan. Tanaman tebu memiliki lima stadium pertumbuhan yaitu fase perkecambahan, pertunasan, pemanjangan batang, kemasakan dan kematian, kebutuhan akan sumberdaya air pada setiap stadium berbeda. Stadium perkecambahan sampai pemanjangan batang dapat dikatakan menghendaki kebutuhan air yang sangat banyak. Namun pada fase kemasakan dan bahkan kematian, kebutuhan terhadap air justru pada kondisi yang lebih sedikit untuk mengoptimalkan pengisian gula dalam batang. Tidak terpenuhi salah satu atau lebih sumberdaya alam yang dibutuhkan tanaman tebu, maka akan berakibat pada penurunan kualitas pertumbuhan maupun produktivitas tanaman yang dihasilkan. Dalam budidaya tebu, upaya untuk memenuhi kebutuhan sumberdaya alam pada saat optimal diperlukan akan memberikan hasil panen yang maksimal (Gunawan \& Wicaksono, 2017).

Indonesia merupakan salah satu negara dengan potensi penghasil gula yang cukup besar. Dengan posisi berada di bawah garis katulistiwa, merupakan modal yang cukup baik untuk menjadikan Negara agraris ini sebagai sewasembada gula. Namun fakta berkata lain, sejak awal tahun 1990an hingga sekarang ini Indonesia selalu mengimpor gula yang setiap tahunnya lebih dari 500 ribu ton gula impor masuk ke Indonesia yang mayoritas penduduknya adalah petani. Dalam 10 tahun terakhir luas areal perkebunan tebu di Indonesia terus meningkat dengan pertumbuhan rata-rata sebesar $3,75 \%$ per tahun dari hanya seluas 340.660 ha pada 2000 meningkat menjadi 473.841 ha tahun 2009 . Pada periode 2008 dan 2009 terjadi peningkatan yang relatif kecil hanya 2,9\% dari 460 ribu ha menjadi 473 ribu ha; hal ini disebabkan karena harga gula anjlok pada saat itu, sehingga menurunkan minat petani tebu untuk menanam tebu. Dengan luas areal 2009 mencapai 473 ribu ha, produksi tebu 2,85 juta ton, produktivitas tebu 5,1 ton per ha, rendemen $7,83 \%$, produksi hablur 2,6 juta ton dan produktivitas hablur 5,96 ton per ha (Anonymous, 2010). Produksi gula merupakan sinergi dari produktivitas tanaman tebu sebagai bahan baku dan kinerja pabrik gula. Pada tanaman, produktivitas ditentukan oleh faktor genetik yaitu varietas, faktor lingkungan yaitu teknik budidaya dan interaksi keduanya. Produktivitas tanaman akan optimal kalau kedua faktor tersebut dikelola dengan baik (Ahmad, S. 2013).

Kesuburan tanah menentukan keberhasilan budidaya tebu, menyangkut aspek faktor pembatas fisik dan kimia tanah. Sifat fisik tanah yang menonjol 
adalah drainase / permeabilitas, tekstur dan ruang pori. Sedangkan sifat kimia tanah adalah kadar bahan organik, $\mathrm{pH}$, ketersediaan hara esensial dan KTK tanah. Tekstur tanah yang sesuai bagi tanaman tebu berdasarkan sifat olah tanah adalah sedang sampai berat atau menurut klasifikasi tekstur tanah (Buckman and Brady, 1960) adalah lempung, lempung berpasir, lempung berdebu, liat berpasir, liat berlempung, liat berdebu dan liat atau yang tergolong bertekstur agak kasar sampai halus. Kemasaman tanah $(\mathrm{pH})$ yang terbaik untuk tanaman tebu adalah pada kisaran 6,0 - 7,0 namun masih dapat tumbuh pada kisaran $\mathrm{pH}$ 4,5 - 7,5. Kesuburan tanah (status hara), berdasarkan hasil penelitian P3GI untuk menentukan kesesuaian lahan bagi tanaman tebu dengan kriteria $\mathrm{N}$ total $>1,5$, $\mathrm{P}_{2} \mathrm{O}_{5}$ tersedia $>75 \mathrm{ppm}, \mathrm{K}_{2} \mathrm{O}$ tersedia $>150 \mathrm{ppm}$. Masa tanam (pola I) yang optimal pada akhir musim kemarau sampai awal musim hujan atau masa tanam juga dapat pada akhir musim hujan sampai awal musim kemarau (pola II) dengan kondisi tanah ringan, tanah dapat diolah sepanjang musim. Pada daerah basah (bulan kering $\leq 2$ bulan) masa tanam tebu terbaik pada awal musim kemarau (Anonymous, 2008).

Menurut Simanungkalit $d k k$. (2006), bahwa berbagai hasil penelitian mengindikasikan bahwa sebagian besar lahan pertanian intensif menurun produktivitasnya dan telah mengalami degradasi lahan, terutama terkait dengan sangat rendahnya kandungan $\mathrm{C}$-organik dalam tanah, yaitu $<2 \%$, bahkan pada banyak lahan sawah intensif di Jawa kandungannya $<1 \%$. Padahal untuk memperoleh produktivitas optimal dibutuhkan C-organik $>2,5 \%$. Di lain pihak, sebagai negara tropika basah yang memiliki sumber bahan organik sangat melimpah, tetapi belum dimanfaatkan secara optimal.

Peningkatan usaha peternakan sapi selain memberikan dampak positif yaitu menghasilkan produk utama seperti daging, susu, dan telur juga memberikan dampak negatif karena usaha peternakan pasti menghasilkan limbah. Limbah ternak merupakan sisa buangan dari suatu kegiatan usaha meliputi : limbah padat dan cair seperti feses,urine dan sisa pakan. Semakin besar skala usaha, limbah yang dihasilkan semakin banyak. Berdasarkan beberapa penelitian yang telah dilakukan tercatat bahwa satu ekor sapi rata-rata menghasilkan kotoran rata-rata 10-25 kg/hari. Apabila dalam satu kandang kolektif dipelihara sebanyak 100 ekor sapi maka kotoran yang dapat dikumpulkan adalah $2.500 \mathrm{~kg}$. Namun sampai saat ini kotoran sapi yang dihasilkan umumnya dibuang ke saluran air untuk bisa dimanfaatkan untuk lahan-lahan yang terairi oleh saluran tersebut. Pada saat yang demikian (kotoran ternak segar) belum dapat dimanfaatkan secara langsung oleh tanaman karena belum terdekomposisi dengan rasio $\mathrm{C} / \mathrm{N}$ lebih dari 40. Diperlukan suatu tindakan alternatif penanganan limbah untuk meminimalisasikan dampak negatif dari peningkatan usaha peternakan. Salah satu cara untuk mereduksi beban pencemaran akibat limbah peternakan adalah dengan menerapkan teknologi bersih adalah dengan memanfaatkan limbah urine dan feses sapi menjadi material penyubur atau pupuk setelah melalui proses pengolahan atau fermentasi guna menjadi pupuk organik yang bermanfaat bagi tanaman (Oginawati dkk., 2013).

Beberapa hasil penelitian membuktikan bahwa urine sapi mengandung zat pengatur tumbuh seperti IAA yang mempunyai pengaruh positip terhadap pertumbuhan vegetatif tanaman; disamping itu aroma urine yang khas dapat mencegah datangnya berbagai hama tanaman, sehingga dapat berfungsi sebagai 
pengendali hama tanaman. Urine sapi juga menghasilkan unsur hara primer seperti Nitrogen (N) 1\%, Phosfor (P) 0.5\% dan Kalium (K) 1.5\% (lingga, 1991).

Pembuatan pupuk cair dari urine sapi harus melalui beberapa proses, proses yang terpenting yang harus dilakukan adalah fermentasi, dimana untuk proses fermentasi, baik secara aerob (memerlukan oksigen) maupun an aerob (tidak memerlukan oksigen) dengan memanfaatkan hasil aktifitas dari mikroorganisme yang mampu mengubah atau mentranspormasikan senyawa kimia kesubtrat organik.

Hormon yang terdapat dalam tanaman tersebut jumlahnya hanya sedikit oleh karena itu penambahan zat ataupun hormon yang mendukung pertumbuhan akar maupun batang. Dengan demikian diharapkan pertumbuhan tanaman menjadi lebih cepat. Misalnya pada pembuatan stek, tanpa pemberian hormon atau zat perangsang tumbuh akar pada stek akan tumbuh agak lama, dan dengan penambahan hormon pada luka ataupun media maka akar pada stek akan tumbuh lebih cepat.

Manfaat dan Kandungan kimiawi yang terdapat pada urine (air kencing) sapi ternyata membawa dampak besar bagi pertanian yang mengembangkan sistem atau pola tanam organik. Selama ini para petani di Indonesia kebanyakan masih kurang memperhatikan khasiat yang sangat ampuh pada air kencing binatang ternak ini, limbah cair peternakan ini sering di buang begitu saja. Namun di balik bau yang pesing terkandung berbagai zat-zat yang di butuhkan oleh tanaman, kandungan kimiawi urine sapi sangat komplek seperti nitrogen , fosfor, kalium (NPK) dan beberapa unsur kimiawi yang lainnya. Dengan demikian urine atau air kencing sapi sangat layak menggantikan pupuk kimia karena memiliki komposisi utamanya adalah Nitrogen $(\mathrm{N}): 1,4$ hingga 2,2 \% , fosfor ( $\mathrm{P}$ ) : 0,6 hingga 0,7\% , dan kalium ( $\mathrm{K}$ ) 1,6 hingga 2,1\% . Karena lengkapnya beberapa unsur hara yang dibutuhkan oleh tanaman untuk tumbuh kembang sehingga urine sapi merupakan solusi murah untuk memenuhi kebutuhan pupuk dalam budidaya pertanian (Anonymous, 2014).

Pupuk organik cair adalah larutan dari hasil pembusukan bahan-bahan organik yang berasal dari sisa tanaman, kotoran hewan dan manusia yang kandungan unsur haranya lebih dari satu unsur. Kelebihan dari pupuk organik ini adalah mampu mengatasi defisiensi hara secara cepat, tidak bermasalah dalam pencucian hara, dan juga mampu menyediakan hara secara cepat. Jika dibandingkan dengan pupuk anorganik, pupuk organik cair umumnya tidak merusak tanah dan tanaman meskipun sudah digunakan sesering mungkin, selain itu pupuk ini juga memiliki bahan pengikat sehingga larutan pupuk yang diberikan ke permukaan tanah bisa langsung dimanfaatkan oleh tanaman (Hadisuwito, 2012). Hasil penelitian Alfarisi dan Manurung (2015), bahwa menunjukkan bahwa pupuk organik urin sapi berpengaruh nyata dapat meningkatkan pertumbuhan dan produksi jagung manis (Zea mays saccharata L). pada konsentrasi $75 \mathrm{cc}$ per liter memberikan pengaruh yang lebih baik terhadap pertumbuhan dan produksi jagung manis.

Hasil uji laboratorium dari Balai Penelitian dan Konsultasi Industri (2017) membuktikan bahwa pupuk organik Cair urine sapi ini mengandung unsur makro seperti C Organik 1,460\%; Nitrogen 0,098\%; $\mathrm{P}_{2} \mathrm{O}_{5}$ 0,102\%; $\mathrm{K}_{2} \mathrm{O} 0,216 \%$; $\mathrm{Ca}$ 166,52 ppm; Mg 104,61 ppm maupun unsur mikro, antara lain : Co 2,15 ppm; Al 2,88 ppm; Fe 0,13 ppm; Na 1,28 ppm; Ni 0,21 ppm; Zn 0,23 ppm; B 1,13 ppm; 
Mn 0,012 ppm juga terdapat beberapa hormon yaitu IAA 8,61 ppm; sitokinin 5,16 ppm; giberillin 2,54 ppm serta kandungan bakteri, seperti : bakteri pelarut pospat, Lactobacillus, Actinomycetes dan bakteri photosintetik.

Dalam perencanaan budidaya tebu, beberapa hal yang harus diperhitungkan, antara lain : ketersediaan bahan tanam, pengolahan yang baik, pemupukan dan tindakan pemeliharaan tanaman lainnya. Salah satu usaha yang dapat ditempuh untuk mengatasinya hal tersebut adalah dengan aplikasi pemupukan pupuk organik cair (POC) yang berasal dari limbah cair peternakan sapi yaitu pupuk yang mengandung unsur hara yang memiliki karakteristik slow release (lepas lambat) serta mengandung zat pengatur tumbuh bagi tanaman.

Oleh karena itu tujuan penelitian dengan menggunakan limbah cair peternakan sapi sebagai aplikasi pupuk organik cair bagi pertumbuhan awal tanaman tebu adalah mengetahui pengaruh pemberian konsentrasi pupuk organik cair urine sapi yang paling efektif dan efisien terhadap laju pertumbuhan awal atau perkecambahan stek bud chip tanaman tebu.

\section{METODE PENELITIAN}

Percobaan dilakukan di Kebun percobaan Universitas Merdeka Surabaya, dengan ketinggian tempat kurang lebih 5 meter diatas permukaan laut. Bahan percobaan meliputi stek bud chips stek tebu PS-881, tanah dan pupuk kandang sebagai media dengan perbandingan $3: 1$. Sebagai perlakuan digunakan Pupuk Organik Cair urine sapi, dimana POC ini dibuat larutan dulu dengan berbagai konsentrasi sesuai perlakuan yang diteliti, kemudian larutan tersebut diberikan pada masing-masing perlakuan berdasarkan volume larutan POC sebanyak $300 \mathrm{ml}$ dan waktu pemberian yang sama yaitu saat tanam, 7 hari, 14 hari, 21 hari, dan 28 hari setelah tanam.

Penelitian ini menggunakan Rancangan Acak Kelompok (RAK), dimana perlakuannya menggunakan satu (1) faktor yaitu Konsentrasi Pupuk Organik Cair Plus (P) terdiri dari 8 level perlakuan dan diulang 3 kali dengan tiap-tiap perlakuan terdapat 2 tanaman sampel, sehingga diperoleh 24 perlakuan. Adapun perlakuan tersebut, antara lain: $\mathrm{P} 0=0 \mathrm{ml} ; \mathrm{P} 1=10 \mathrm{ml} ; \mathrm{P} 2=20 \mathrm{ml} ; \mathrm{P} 3=30$ $\mathrm{ml} ; \mathrm{P} 4=40 \mathrm{ml} ; \mathrm{P} 5=50 \mathrm{ml} ; \mathrm{P} 6=60 \mathrm{ml} ; \mathrm{P} 7=70 \mathrm{ml}$ POC per liter air.

\section{HASIL DAN PEMBAHASAN}

\subsection{Kecepatan Perkecambahan, Diameter Batang, Jumlah Daun dan Panjang Akar}

Hasil analisis statistik menunjukkan bahwa perlakuan konsentrasi Pupuk Organik Cair (POC) dari limbah urine sapi memberikan pengaruh tidak nyata (Fhitung < F5\%) terhadap variabel kecepatan perkecambahan, diameter tunas, jumlah daun serta panjang akar pada tahapan perkecambahan stek bud chip, sebagaimana hasil sidik ragam pada uji F. Adapun rata-rata hasil pengamatan variabel tersebut akibat perlakuan konsentrasi POC urine sapi pada stek bud chip tanaman tebu pada awal pertumbuhan tebu, disajikan pada tabel 1.

Pada tabel 1 dibawah menunjukkan bahwa dari perlakuan berbagai konsentrasi POC urine sapi pada stek bud chip tebu terlihat perlakuan P2 dan P3 cenderung memberikan nilai lebih baik yaitu 3,00 hari dan 3,17 hari dibandingkan perlakuan lainnya, meskipun secara statistik semua perlakuan yang diteliti tidak berbeda nyata. Sedangkan jika dihitung prosentase peningkatan kecepatan 
perkecambahan terhadap perlakuan kontrol menunjukkan bahwa perlakuan P2 memberikan percepatan laju perkecambahan sebesar 9,91\% sedangkan P3 sebesar $4,80 \%$ dibandingkan perlakuan kontrol. Kemudian hasil pemberian berbagai konsentrasi POC urine sapi pada stek bud chip tebu pada variable diameter tunas akhir pengamatan (35 hst) terlihat bahwa semua perlakuan yang diteliti mulai P1 hingga P7 cenderung memberikan respon yang lebih baik dengan memberikan nilai lebih baik dibandingkan perlakuan kontrol. Demikian juga pada variabel jumlah daun terlihat perlakuan P1 hingga P7 cenderung memberikan nilai lebih baik dibandingkan dengan perlakuan kontrol, meskipun secara statistik berbeda tidak nyata dengan semua perlakuan yang diteliti pada berbagai umur pengamatan tanaman. Pada variabel panjang akar menunjukkan juga bahwa perlakuan P3 cenderung memberikan nilai lebih baik yaitu $46,02 \mathrm{~cm}$ dengan prosentase peningkatan terhadap perlakuan kontrol sebesar 23,28 \% dibandingkan dengan perlakuan lainnya, meskipun secara statistik berbeda tidak nyata dengan perlakuan lainnya pada pengamatan umur 35 hari setelah tanam.

Tabel 1. Hasil Mean Pengamatan Kecepatan Perkecambahan, Diameter Batang Tunas, Jumlah Daun dan Panjang Akar Stek Bud Chip Tanaman Tebu.

\begin{tabular}{|c|c|c|c|c|}
\hline \multirow{2}{*}{ Perlakuan } & \multicolumn{4}{|c|}{ Nilai Mean Hasil Pengamatan } \\
\cline { 2 - 5 } & $\begin{array}{c}\text { Kecepatan } \\
\text { Perkecambahan }\end{array}$ & $\begin{array}{c}\text { Diameter Batang } \\
\text { (35 HST) }\end{array}$ & $\begin{array}{c}\text { Jumlah Daun } \\
\text { (35 HST) }\end{array}$ & $\begin{array}{c}\text { Panjang Akar } \\
\text { (35 HST) }\end{array}$ \\
\hline P0 & 3.33 & 0.95 & 3.67 & 37.33 \\
\hline P1 & 3.33 & 1.03 & 4.33 & 38.97 \\
\hline P2 & 3.00 & 1.03 & 4.67 & 44.12 \\
\hline P3 & 3.17 & 1.02 & 4.33 & 46.02 \\
\hline P4 & 3.33 & 1.03 & 4.00 & 41.28 \\
\hline P5 & 3.50 & 1.02 & 4.17 & 42.02 \\
\hline P6 & 3.33 & 1.12 & 4.67 & 40.47 \\
\hline P7 & 3.33 & 1.08 & 4.50 & 40.28 \\
\hline BNT 5\% & tn & tn & tn & tn \\
\hline
\end{tabular}

Keterangan: Angka-angka yang didamping huruf yang sama, pada kolom yang sama menunjukkan tidak berbeda nyata (BNT 5\%).

Selanjutnya grafik yang menunjukkan pola hasil pengamatan variabel diameter batang, jumlah daun pada tahapan perkecambahan stek bud chip, disajikan dibawah ini. 


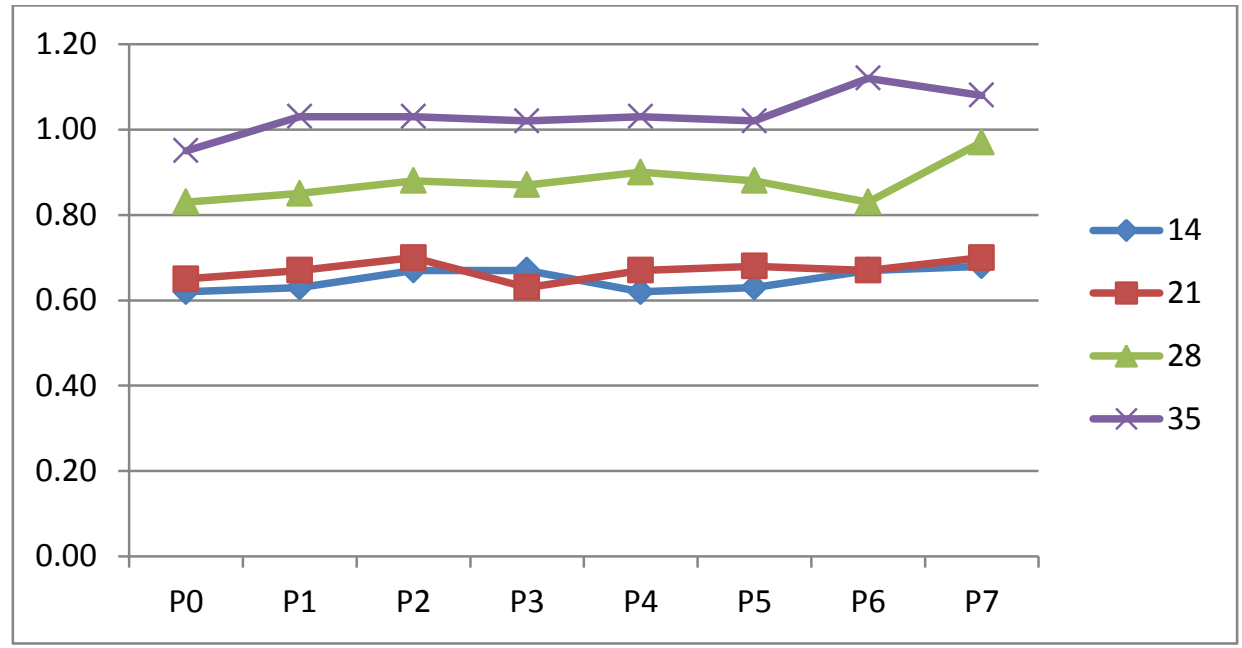

Grafik 1. Pola Nilai Diameter Batang Tunas Pada Tahapan Perkecambahan Stek Bud Chip Pada Berbagai Umur Pengamatan.

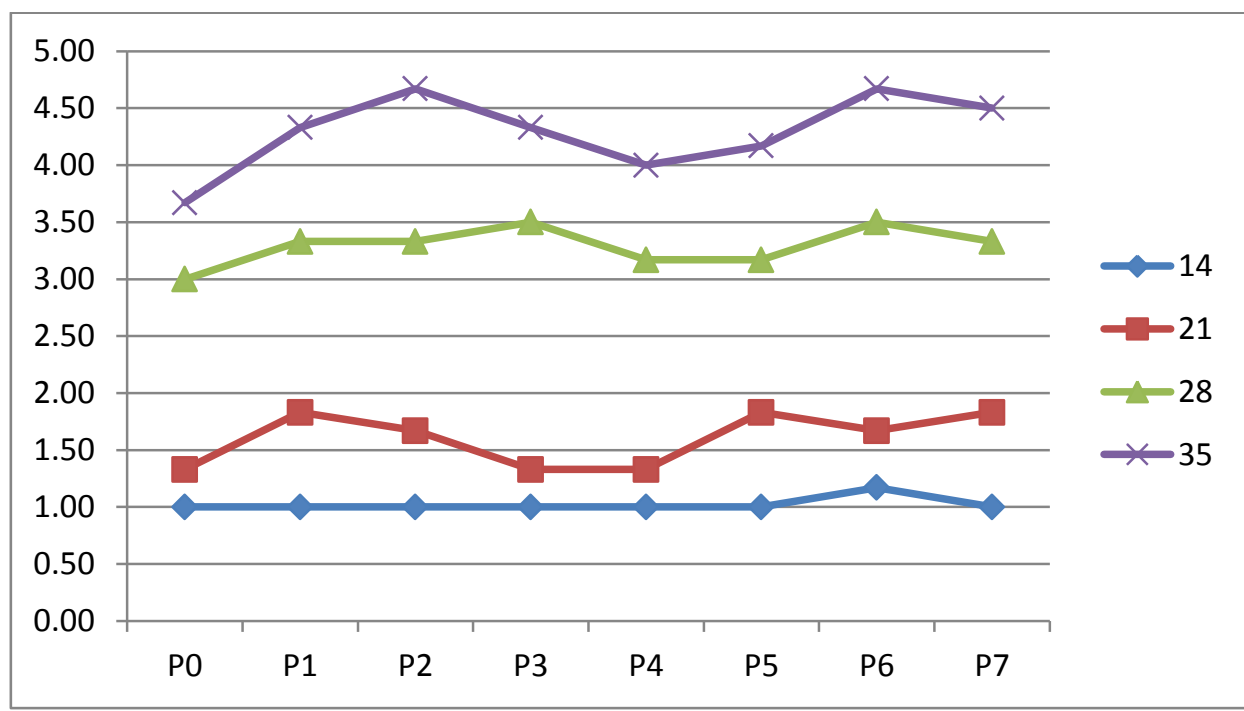

Grafik 2. Pola Nilai Jumlah Daun Pada Tahapan Perkecambahan Stek Bud Chip Pada Berbagai Umur Pengamatan.

Hasil penelitian ini memberikan gambaran bahwa pemberian pupuk organik cair urine sapi berpengaruh pada peningkatan efek fisiologis tumbuhan pada masa perkecambahan stek bud chip tebu, khususnya pada perlakuan P2 dan P3 sehingga terjadi percepatan perkecambahan dibandingkan dengan perlakuan kontrol. Pupuk adalah makanan bagi seluruh jenis tanaman, tanaman mengambil makanan dengan cara menyerapnya melalui ujung akar yang baru tumbuh dan atau pada tahap awal perkecambahan stek bud chip secara optimal memanfaatkan energi dari cadangan makanan pada bagian stek bud chip di sekitar tunas, sehingga memberikan pengaruh yang tidak berbeda nyata pada variabel kecepatan perkecambahan pada semua perlakuan yang diteliti. 
Penggunaan pupuk organik tersebut merupakan implementasi dari konsep pertanian ekologis dengan mempertimbangkan efisiensi biaya produksi. Teknologi dalam proses produksi pupuk cair ini adalah menciptakan suatu unsur hara yang memiliki karakteristik unik yang juga mengandung hormon pertumbuhan seperti IAA, sitokinin, dan giberillin juga mikroorganisme yang berperan meningkatkan ketersediaan usur hara bagi tanaman, sehingga secara keseluruhan pupuk organik cair ini mampu berperan merangsang dan meningkatkan pertumbuhan akar, batang, daun dan anakan dengan cepat.

Pemupukan adalah tindakan memberikan tambahan unsur-unsur hara pada komplek tanah, baik langsung maupun tak langsung dapat menyumbangkan bahan nutrisi pada tanaman. Tujuannya untuk memperbaiki tingkat kesuburan tanah agar tanaman mendapatkan nutrisi yang cukup untuk meningkatkan kualitas dan kuantitas pertumbuhan tanaman. Menurut Harjadi, S. (1991), bahwa Organ daun berperan sebagai produsen fotosintat utama selama proses fotosintesis berlangsung, dimana hasil fotosintat tersebut selanjutnya berpengaruh penting dalam pertumbuhan dan pembentukan biomassa tanaman. Fotosintesis adalah proses dimana karbondioksida dan air dengan pengaruh cahaya matahari serta adanya klorofil dirubah kedalam persenyawaan organik yaitu karbohidrat yang kaya energi.

\subsection{Panjang Tunas, Jumlah Akar dan Berat Kering per Tanaman}

Hasil analisis statistik menunjukkan bahwa perlakuan konsentrasi Pupuk Organik Cair (POC) dari limbah urine sapi juga memberikan pengaruh nyata (Fhitung > F5\%) terhadap variabel panjang tunas, jumlah akar dan berat kering per tanaman pada tahapan perkecambahan stek bud chip, sebagaimana hasil sidik ragam pada uji $\mathrm{F}$. Adapun rata-rata hasil pengamatan tersebut akibat perlakuan konsentrasi POC urine sapi pada stek bud chip tanaman tebu pada tahap perkecambahan, disajikan pada tabel 2.

Tabel 2. Hasil Mean Pengamatan Panjang Tunas, Jumlah Akar dan Berat Kering per Tanaman Stek Bud Chip Tanaman Tebu (cm) pada Umur 35 Hari Setelah Tanam.

\begin{tabular}{|c|c|c|c|}
\hline \multirow{2}{*}{ Perlakuan } & \multicolumn{3}{|c|}{ Nilai Mean Hasil Pengamatan } \\
\cline { 2 - 4 } & Panjang Tunas & Jumlah Akar & $\begin{array}{c}\text { Berat Kering per } \\
\text { Tanaman }\end{array}$ \\
\hline P0 & $74.72 \mathrm{a}$ & $13.67 \mathrm{a}$ & $4.30 \mathrm{a}$ \\
\hline P1 & $85.60 \mathrm{ab}$ & $14.50 \mathrm{ab}$ & $5.43 \mathrm{ab}$ \\
\hline P2 & $93.77 \mathrm{~b}$ & $15.33 \mathrm{ab}$ & $5.88 \mathrm{bc}$ \\
\hline P3 & $93.17 \mathrm{~b}$ & $18.17 \mathrm{bc}$ & $5.87 \mathrm{bc}$ \\
\hline P4 & $90.75 \mathrm{~b}$ & $18.33 \mathrm{bc}$ & $5.72 \mathrm{bc}$ \\
\hline P5 & $96.38 \mathrm{~b}$ & $19.50 \mathrm{c}$ & $6.08 \mathrm{bc}$ \\
\hline P6 & $92.28 \mathrm{~b}$ & $18.17 \mathrm{bc}$ & $6.62 \mathrm{bc}$ \\
\hline P7 & $97.87 \mathrm{~b}$ & $19.33 \mathrm{c}$ & $6.72 \mathrm{c}$ \\
\hline BNT 5\% & 12.75 & 4.01 & 1.28 \\
\hline
\end{tabular}

Keterangan : Angka-angka yang didamping huruf yang sama, pada kolom yang sama menunjukkan tidak berbeda nyata (BNT 5\%). 
Pada tabel 2 diatas menunjukkan dari pemberian berbagai konsentrasi POC urine sapi pada stek bud chip tebu bahwa pada variabel panjang tunas, jumlah akar maupun berat kering per tanaman menunjukkan perlakuan P1 hingga P7 memberikan pengaruh lebih baik dibanding perlakuan kontrol, meskipun perlakuan P7 memberikan nilai tertinggi masing-masing sebesar 97,87 cm; 19,33 dan 6,72 gram dibandingkan perlakuan lainnya, namun secara statistik variabel panjang tunas menunjukkan bahwa perlakuan P1 hingga P7 berbeda tidak nyata, sedangkan variabel jumlah akar menunjukkan bahwa perlakuan P3 hingga P7 berbeda tidak nyata, demikian juga variabel berat kering per tanaman menunjukkan bahwa perlakuan P2 hingga P7 berbeda tidak nyata. Selanjutnya grafik yang menunjukkan pola pengamatan tersebut pada tahapan perkecambahan stek bud chip, disajikan dibawah ini.

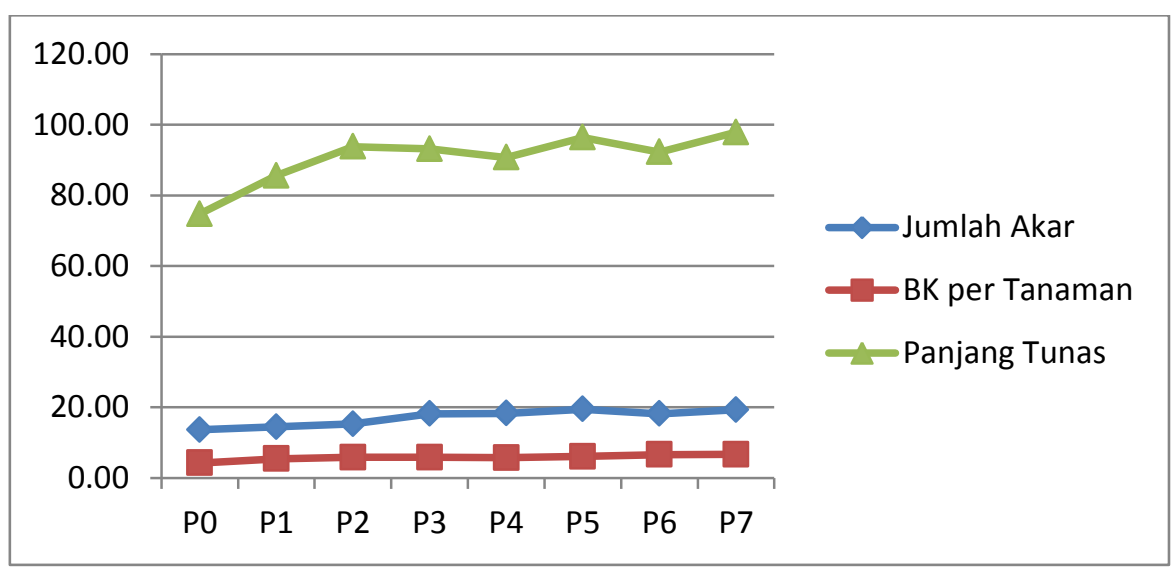

Grafik 3. Pola Nilai Panjang Tunas, Jumlah Akar dan Berat Basah Dan Berat Kering Per Tanaman Pada Tahapan Perkecambahan Stek Bud Chip Pada Akhir Pengamatan (35 HST).

Bahan organik yang ditambahkan pada media tanam juga berperan sebagai sumber energi dan makanan mikroba tanah sehingga dapat meningkatkan aktivitas mikroba tersebut dalam penyediaan hara tanaman. Jadi penambahan bahan organik di samping sebagai sumber hara bagi tanaman, sekaligus sebagai sumber energi dan hara bagi mikroba. Kandungan bakteri dalam POC urine sapi ini, seperti bakteri photosintetik merupakan mikroba yang mampu berperan meningkatkan kapasitas fotosintesis tanaman dan Lactobacillus sp. merupakan mikroba yang berperan dalam membantu proses fermentasi bahan organik menjadi senyawa-senyawa asam laktat yang dapat diserap tanaman. Sedangkan mikroba pelarut pospat merupakan mikroba yang berfungsi membantu melarutkan unsur $\mathrm{P}$ dalam pupuk pospat (TSP, SP-36, SP-18) maupun unsur $\mathrm{P}$ yang terikat jerapan liat silikat tanah, sehingga menjadi senyawa pospat yang tersedia dan mudah diserap oleh tanaman (BPKI, 2017).

Bahan/pupuk organik sangat bermanfaat bagi peningkatan produksi pertanian baik kualitas maupun kuantitas, mengurangi pencemaran lingkungan, dan meningkatkan kualitas lahan secara berkelanjutan. Penggunaan pupuk organik dalam jangka panjang dapat meningkatkan produktivitas lahan dan dapat mencegah degradasi lahan. Sumber bahan untuk pupuk organik sangat beranekaragam, dengan karakteristik fisik dan kandungan kimia/hara yang sangat 
beragam sehingga pengaruh dari penggunaan pupuk organik terhadap lahan dan tanaman dapat bervariasi (Simanungkalit $d k k ., 2006$ ).

Hasil uji laboratorium dari Balai Penelitian dan Konsultasi Industri (2017) membuktikan bahwa pupuk organik Cair urine sapi ini mengandung unsur makro maupun unsur mikro juga dilengkapi beberapa hormon yaitu IAA, sitokinin, GA3 yang sangat berperanan dan dibutuhkan bagi pertumbuhan dan perkembangan tanaman, disamping juga terdapat kandungan mikroorganisme yang membantu ketersediaan unsur hara bagi tanaman. Menurut Subroto dan Awang (2005), bahwa unsur $\mathrm{N}, \mathrm{P}$ dan $\mathrm{K}$ tergolong unsur makro untuk sebagian besar tanaman, sebagain besar tanaman menyerap unsur $\mathrm{P}$ dalam bentuk orthofosfat $\mathrm{H}_{2} \mathrm{PO}_{4}{ }_{4}$, sepuluh kali lebih sedikit dalam bentuk orthofosfat sekunder $\mathrm{HPO}_{4}{ }^{2-}$ penyerapan unsur tersebut dipengaruhi oleh $\mathrm{pH}$ tanah disekitar perakaran tanaman. Bila $\mathrm{pH}$ tanah rendah (masam), maka penyerapan unsur $\mathrm{P}$ dalam (bentuk orthofosfat primer. Sedangkan bila nilai $\mathrm{pH}$ tinggi, akan meningkatkan penyerapan unsur $\mathrm{P}$ dalam bentuk Orthofosfat sekunder. Pasokan unsur $\mathrm{P}$ yang sangat penting bagi tanaman adalah pada saat awal pertumbuhan tanaman, dapat merangsang pertumbuhan akar tanaman, sehingga dapat meningkatkan penyerapan unsur hara lainnya dalam tanah.

Pupuk organic cair ini memiliki fungsi kimia yang penting seperti: (1) penyediaan hara makro (N, P, K, Ca, Mg, dan $\mathrm{S}$ ) dan mikro seperti $\mathrm{Zn}, \mathrm{Cu}, \mathrm{Mo}$, $\mathrm{Co}, \mathrm{B}, \mathrm{Mn}$, dan Fe, meskipun jumlahnya relatif sedikit. Penggunaan pupuk organik cair ini dapat mencegah kahat unsur mikro pada tanah marginal atau tanah yang telah diusahakan secara intensif dengan pemupukan yang kurang seimbang; (2) meningkatkan kapasitas tukar kation (KTK) tanah; dan (3) dapat membentuk senyawa kompleks dengan ion logam yang meracuni tanaman seperti $\mathrm{Al}, \mathrm{Fe}$, dan $\mathrm{Mn}$.

\section{KESIMPULAN}

Berdasarkan hasil penelitian, maka dapat disimpulkan sebagai berikut :

1. Terdapat pengaruh signifikan dari konsentrasi POC urine sapi terhadap peningkatan pertumbuhan stek bud chip tanaman tebu pada variabel yang diteliti, meliputi : panjang tunas, jumlah akar maupun berat kering per tanaman pada masa perkecambahan tanaman tebu.

2. Nilai tertinggi dicapai oleh perlakuan P7 yaitu konsentrasi sebesar $70 \mathrm{ml}$ POC urine sapi per liter air pada semua parameter pengamatan yang diteliti; namun secara statistik nilai terbaik dicapai oleh perlakuan P3 $(30 \mathrm{ml}$ POC urine sapi per liter air) karena berbeda tidak nyata dengan perlakuan P7 pada semua variabel yang diteliti, seperti kecepatan perkecambahan, panjang tunas, jumlah daun, panjang akar, jumlah akar, dan berat kering per tanaman karena dianggap lebih efektif dan efisien. 


\section{DAFTAR PUSTAKA}

Ahmad, S. 2013. Melaju Bersama Varietas Menuju Swasembada Gula 2014. dalam http://pusatpenelitiangula.blogspot.com/2013/02/melaju-bersamavarietas-menuju.html\#more

Alfarisi, N. dan Manurung, T., 2015. Pengaruh pemberian pupuk urine sapi terhadap pertumbuhan dan produksi jagung manis dengan menggunakan EM-4. Biologi Unimed. Jurnal Bio Sains Vol.1 No.3 Desember 2015.

Anonymous, 2014. Kandungan Kimiawi Urine Sapi Untuk Pertanian dalam http://www.organikilo.co/2014/12/kandungan-kimiawi-urine-sapi-untuk. html

Anonymous, 2010. Pengembangan Perkebunan Gula Dalam Menuju Swasembada Gula. dalam : http://www.datacon.co.id/Agri-2010 Gula.html). 2008. Konsep Budidaya Tanaman Tebu.dalam http://cerianetagricultur. blogspot.com/2008/12/konsep-budidaya-tebu.html

Balai Penelitian dan Konsultasi Industri, 2017. Hasil Uji Laboratorium Pupuk Organik Urine Sapi. Surabaya.

Harjadi, S. 1991. Pengantar Agronomi. PT Gramedia Jakarta. 195 pp.

Oginawati, K., Khoerunisa, R., Nur Hijrah, S. 2013. Penanganan Limbah Padat dan Limbah Cair Usaha Peternakan. Institut Teknologi Bandung.

Simanungkalit, RDM., Didi Ardi Suriadikarta, Rasti Saraswati,Diah Setyorini, dan Wiwik Hartatik, 2006. Pupuk Organik dan Pupuk Hayati (Organic Fertilizer and Biofertilizer). Balai Besar Litbang Sumberdaya Lahan Pertanian Badan Penelitian dan Pengembangan Pertanian. Bogor.

Subroto dan Awang Yusrani. 2005. Kesuburan dan Pemanfaatan Tanah. IB Bayumedia. Malang. 100 hal.

Yitnosumarto. S. 1991. Percobaan : Perancangan, Analisis dan Interprestasinya. Dep. P dan K Program MIPA Universitas Brawijaya. Malang. 